\title{
RED DRAGON FRUIT JUICE IN REDUCING BLOOD SUGAR LEVEL IN RATS WITH TYPE 2 DIABETES MELITUS
}

\author{
Mahendri Deayu Putri'), Budiyanti Wiboworini²), \\ Paramasari Dirgahayu3)
}

\author{
1)Masters Program in Clinical Nutrition and Nutrition Sciences, \\ Universitas Sebelas Maret \\ 2)Department of Nutrition, Faculty of Medicine, Universitas Sebelas Maret \\ 3)Department of Public Health, Faculty of Medicine, Universitas Sebelas Maret
}

\begin{abstract}
Background: Previous studies reported that red dragon fruit is a rich source of antioxidant, polyphenolic, and flavonoid. These components can attenuate serum fibroblast growth factor-21 (FGF-21) resistance, improve insulin resistance, reduce oxidative stress, and preserve pancreatic beta-cell function, which is related to blood sugar level. This study aimed to examine red dragon fruit juice in reducing blood sugar level in rats with type 2 diabetes mellitus (DM).

Subjects and Method: This was a randomized controlled trial. 28 male wistar rats (Rattusnorvegicus) was selected for this study and randomly allocated into four groups: (1) Positive control group, (2) Negative control group (induced with Streptozotocin and Nicotinamide), (3) Metformin group (induced with Streptozotocin, Nicotinamide, and Metformin $\mathrm{HCl} 0.9 \mathrm{mg} / \mathrm{kgBW}$ ), and (4) Red dragon fruit group (induced with Streptozotocin, Nicotinamide, and Red dragon fruit juice $3.6 \mathrm{ml} / 200 \mathrm{gBW} /$ day). The dependent variable was blood glucose level. The independent variable was antidiabetic agent, either Metformin or Red dragon juice, provided for 14 days. The data were analyzed by One Way Anova and post-hoc test.

Results: Before intervention, the mean blood glucose levels were comparable among the four study groups, and they were statistically non-significant indicating the randomization had achieved its intended objective. After intervention, the mean blood glucose levels were as follows: positive control group (Mean $=64.58 ; \mathrm{SD}=1.65$ ), negative control group $(\mathrm{Mean}=276.54 ; \mathrm{SD}=7.50)$, Metformin group $(\mathrm{Mean}=120.27 ; \mathrm{SD}=7.48)$, and Red dragon fruit group (Mean=114.58; $\mathrm{SD}=8.19$ ). Both Metformin group and Red dragon fruit group had lower blood glucose level than negative control group, and their pair-wise mean differences were statistically significant $(\mathrm{p}<0.001)$. The mean difference in blood glucose level between the Metformin group and Red dragon fruit group was statistically non-significant $(\mathrm{p}=0.714)$.

Conclusion: Red dragon fruit and Metformin when administered alone is effective to lower blood glucose level in rats with type 2 DM. Red dragon fruit can be used as an alternative to Metformin as their effectiveness in lowering blood glucose level are comparable.
\end{abstract}

Keywords: Red dragon fruit, Metformin, blood glucose level, type 2 diabetes mellitus

\section{Correspondence:}

Mahendri Deayu Putri. Masters Program in Clinical Nutrition, Universitas Sebelas Maret. Jl. Ir. Sutami 36 A, Surakarta 57126, Central Java. Email: mahendrideayu@gmail.com. Mobile: +62 821-4077-6757. 